\title{
A PROSA NÃO QUIXOTESCA DE BANDEIRA FICÇÃO OU POESIA
}

\author{
João Paulo Zarelli Rocha \\ UFSC - CNPq
}

RESUMO: Bandeira, sem ter escrito um conto sequer, conta inúmeras histórias. Em carta a João Cabral, reclama de redondilhas jogadas por seu amigo, como celebração natalina, a um cartão que mais pareciam pulgas de Anatole France. As pulgas provinham de Les matinées de la Villa Saïd, onde um professor Brown, conversando com o próprio Anatole-personagem, retomava os "percevejos que eram como este mahométane!" do Sancho do Quixote de Avellaneda. Já as pulgas de Bandeira, "quisera [ele, Bandeira,] que fossem feitas assim!", não passadistas como o próprio sujeito de Anatole ou como aqueles versos jogados. Como a própria personagem de Anatole, de Avellaneda e o percevejo / a pulga de Bandeira surgem de um espaço insólito compõe a questão deste artigo, dando continuidade à iluminação de Sílvio Elia ao denominar Bandeira de "prosador maior", dada a estranheza da(s) crônica(s) e sua mobilização nessas prosas do poeta e também em sua poesia. Finalmente, lemos o insólito não dado por estórias como devir, apesar da lamentação do Itinerário "Mas eu é que sei que não nasci com bossa para isso [para a prosa]. Bem que o tentei várias vezes."

PALAVRAS-CHAVE: Filologia; Periodismo; Narrativa; Insólito; Crônica.

\section{THE NON-QUIXOTIC PROSE OF BANDEIRA FICTION OR POETRY}

ABSTRACT: Bandeira, without writing a single short story, tells countless histories. In a letter to João Cabral, he complains about septenaries laid out by his friend as Christmas celebration in a postcard that seemed Anatole France's fleas. The fleas came from Les matinées de la Villa Said, where a professor Brown, chatting with the Anatole-character himself, remembered Sancho's "bug beds that were like this Mahometan!" from Avellaneda's Quixote. On the other hand, Bandeira's fleas, he expected, "were done like that!", outdatedly, like Anatole himself, or those laid out verses. How Anatole's own character, Avellaneda and how the flea / bed bug from Bandeira hint a space that arises uncannily compose this essay's question, carrying on Silvio Elia's illumination: Bandeira as a distinguished prose writer; given the defamiliarization in his stories and in his poetry. Finally, the uncanny in such non-short stories is read as becoming, though Bandeira weeps in the Itinerário: "But I know I wasn't born with bossa for prose. Though I tried it many times."

KEYWORDS: Philology; Periodical studies; Narration; Uncanny; Crônica.

João Paulo Zarelli Rocha é mestrando do Programa de Pós-Graduação em Literatura da Universidade Federal de Santa Catarina. 


\title{
A PROSA NÃO QUIXOTESCA DE BANDEIRA FICÇÃO OU POESIA
}

\author{
João Paulo Zarelli Rocha
}

\section{INTRODUÇÃO}

Em muitos poemas de Bandeira, somos guiados por uma voz falando sobre poesia. Rondós, rimancetes, madrigais, baladilhas e haicais, se nos atemos somente às formas clássicas, são recorrentes em sua obra. ${ }^{1}$ Porém, em vez disso ser uma "preocupação de crítico" ou pretensão de poeta-crítico, isto é, em vez de ser mero recurso submisso ao "conteúdo emocional", de poesia sobre poesia que se emancipou suficientemente na memória para se tornar labuta digna de ser poesia, trata-se de um procedimento que conflui com uma autoconsciência e com um projeto de elaboração do Bandeira poeta. ${ }^{2}$ Um po-

1 TELES, Gilberto Mendonça. A experimentação poética de Bandeira. Travessia, v. 5, n. 13, p. 49, 1986. Nos anos 80, a Travessia contou com estudos sobre o poeta nos n. 2, 3, 5, 8/9 e 13, este último intitulado "Manuel Bandeira (1886-1989)". Diferentemente de outras revistas que mencionaremos à frente, preponderam questões formais nesses estudos.

Este ápice sobre problemas deste espectro aparentemente não foi retomado mais tarde por alguma revista, mas se mantém em casos particulares como SILVEIRA, Juliana Fabrícia da. A presença do elemento medieval na poesia de Manuel Bandeira. In: XI Congresso Internacional da ABRALIC: Tessituras, Interações, Convergências, 13-17 jul. 2008, USP; ou TORRES, José William Craveiro. Manuel Bandeira, trovador modernista. In: HERNÁNDEZ, Ascensión Rivas (Ed.). Manuel Bandeira en Pasárgada. Salamanca: Ediciones Universidad de Salamanca, 2015, p. 189-198.

Em nossa apresentação no "Poesia, memória e arquivo II - Manuel Bandeira", "Ficção ou conto, poesia ou prosa: Bandeira e a pulga do Quixote", de onde provém este texto, tínhamos também como objetivo realizar uma espécie de glosa periodista sobre os estudos a respeito de Bandeira. Aproveitamos este espaço dos rodapés para tanto.

${ }^{2}$ Crítico de si era projeto de João Cabral: "Eu nunca escrevi crítica literária. Como eu convivia num meio literário, lá no Recife, preponderantemente de poetas, eu comecei a escrever poesia. Mas sempre escrevi poesia como crítico. Eu me proponho a fazer um poema que o crítico João Cabral, que nunca fez crítica, aprovaria." CARVALHOSA, Carlito; LAGE, Lana; LEITE, Sebastião Uchôa; LIMA, Luiz Costa. João Cabral de Melo Neto. 34 Letras, n. 3, p. 18, 1989; para quem "Ocorre que aos 17 ou 18 anos não se tem cultura nem discernimento para ser crítico. Então eu comecei a fazer poesia apenas para produzir alguma coisa, enquanto me preparava para a crítica. [...] Esse negócio que se chama metapoesia, poesia sobre poesia, é uma preocupação de crítico." [Entrevista a] STEEN, Edla van. Viver e escrever. Porto Alegre: L\&PM, 1981, p. 24-25.

Evidentemente, isso não compunha o projeto todo dele, seja por parte de uma leitura da crítica ou dele mesmo. SOUZA, Helton Gonçalves de. A poesia crítica de João Cabral de Melo Neto. São Paulo: Annablume, 1999.

Por outro lado, mas também em tempos pueris - ou melhor, também rememorando tempos pueris -, Bandeira narra sobre a própria faísca artística como "conteúdo inesgotável de emoção": "A certa altura da vida vim a identificar essa emoção particular com outra - a de natureza artística. Desde esse momento, posso dizer que havia descoberto o segredo da poesia, o segredo do meu itinerário em poesia. Verifiquei ainda que o conteúdo emocional daquelas 
eta que reapropria, é sensível a isso e não é crente de boas resultantes da mera inspiração, o que Drummond exaltava como "negócio de grande responsabilidade". ${ }^{3}$

A partir do procedimento, podemos formalizar Bandeira, dissecar recorrências ou ritmos que ele mobiliza não só em versos. Vem como podemos destacar, nesta mobilização, como o escritor Bandeira constrói um si, um desvencilhamento inescapável à escrita, um vetor significante. ${ }^{4}$

AUTOFICÇÕES

\title{
HIATO $^{5}$
}

\author{
Es NA MINHA vIDA como um luminoso \\ Poema que se lê comovidamente \\ Entre sorrisos e lágrimas de gozo...
}

\begin{abstract}
A cada imagem, outra alma, outro ente Parece entrar em nós e manso enlaçar

A velha alma arruinada e doente...
\end{abstract}

\author{
- Um poema luminoso como a mar, \\ Aberto em sorrisos de espuma, onde as velas \\ Fogem como garças longínquas no ar...
}

reminiscências da primeira meninice era o mesmo de certos raros momentos em minha vida de adulto: num e noutro caso alguma coisa que resiste à análise da inteligência e da memória consciente, e que me enche de sobressalto ou me força a uma atitude de apaixonada escuta." BANDEIRA, Manuel. Itinerário de Pasárgada. Poesia completa e prosa: em um volume. Rio de Janeiro: Nova Aguilar, 1983, p. 34.

3 "Penso ter resolvido as contradições elementares da minha poesia num terceiro volume, Sentimento do mundo (1940). Só as elementares: meu progresso é lentíssimo, componho muito pouco, não me julgo substancialmente e permanentemente poeta. Entendo que poesia é negócio de grande responsabilidade, e não considero honesto rotular-se de poeta quem apenas verseje por dor-de-cotovelo, falta de dinheiro ou momentânea tomada de contato com as forças líricas do mundo, sem se entregar aos trabalhos cotidianos e secretos da técnica, da leitura, da contemplação e mesmo da ação. Até os poetas se armam, e um poeta desarmado é, mesmo, um ser à mercê de inspirações fáceis, dócil às modas e compromissos. Infelizmente, exige-se pouco do nosso poeta; menos do que se reclama ao pintor, ao músico, ao romancista..." ANDRADE, Carlos Drummond de. Confissões de Minas. São Paulo: Cosac Naify, 2011, p. 68.

${ }^{4}$ FOUCAULT, Michel. O que é um autor? Estética, literatura e pintura, música e cinema. Rio de Janeiro: Forense Universitária, 2009.

5 BANDEIRA, Manuel. [Hiato. Carnaval ], Poesia completa e prosa, op. cit., p. 176. Sob o massacrante advento do .epub e do .mobi, optamos por manter as reproduções do texto-base tal qual digitalizadas. A possível transcrição sem rigor nos parece tão potencialmente perigosa quanto não saber que o espaço do disco rígido aumenta exponencialmente (à custa de quê?). 
Diversas também são as intervenções de uma voz nos poemas de Bandeira que desautomatizam uma leitura, guiando-a para uma dicção ou comentário sobre um recurso estilístico, ${ }^{6}$ ou ironizam a escansão quadrada, como o poema "Hiato" mobiliza, mas que também era a problemática até em um verso de um soneto camoniano:

Os parnasianos admitiam o hiato 'dentro da mesma dicção', como dizia o Castilho, e Raimundo Correia escreveu, aliás lindamente, 'A toalha friíssima do lago', mas reprovavam-no de dicção a dicção. Muito inconseqüentemente, por que se aceitavam que se contassem em 'toalha' duas ou três sílabas, como não consentir a contagem de uma ou duas sílabas em 'o ar'?7

Bandeira é um lapidador consciente e valorizador de recursos formais. Um desses recursos que ele usa vastamente em sua produção, não só na poética, é a paráfrase, que discorreremos abaixo sem perder de vista que se tratam de movimentos que acompanham uma espécie de autoficção.

Não é preciso sempre recorrer a Doubrovsky ao se tratar da autoficção, pelo menos não enquanto tratamos da escrita de si mais do que de um romance autoficcional. ${ }^{8}$ Dificilmente um autor não irá compor um ego enquanto ser no mundo, especialmente se ignoramos uma pressão autorizante do que é válido a esta composição. ${ }^{9}$

Sem nos subjugarmos a esta pressão, então, partimos de uma carta de Bandeira a João Cabral para tratarmos sobre ainda outros escritos de si.

\footnotetext{
'Um caso marcante é o poema "Canção de muitas Marias": "Essa foi a Mária Cândida/ (Mária digam por favor),/ Minha Maria enfermeira,/ Tão forte e morreu de gripe,/ Tão pura e não teve sorte,/ Maria do meu amor." A intervenção se dá até como um comentário filológico, entre parênteses. Ibidem, [Lira dos cinquenta anos], p. 257.

7 Ibidem, [Itinerário de Pasárgada], p. 44. Como observável no restante da estrofe, a questão surge de um único verso: "Ondas (dizia), antes que Amor me mate,/ Tornai-me a minha Ninfa, que tão cedo/ Me fizestes à morte estar sujeita./ Ninguém responde; o mar de longe bate;/ Move-se brandamente o arvoredo;/ Leva-lhe o vento a voz, que ao vento deita."

8 DOUBROVSKY, Julien Serge. Pourquoi la nouvelle critique : critique et objectivité. Paris: Mercure de France, 1966.

9 'On est amené à laisser de côté dans l'oeuvre d'un auteur des textes qui ne sont pas pertinents (des oeuvres de jeunesse, des écrits personnels, des opinions un instant avancées puis vite abandonnées). Que signifie dès lors l'auteur? Quel usage fait-on exactement du nom propre? Que désigne-t-on lorsque, dans ces conditions, on dit Darwin ou Cuvier? / Somos levados a deixar de lado, na obra de um autor, textos que não são pertinentes (a obra durante a juventude, os escritos pessoais, opiniões alimentadas por um instante e abandonadas em um instante). O que significa o autor a partir de então? Que uso nós fazemos do nome próprio? O que queremos dizer, nestas condições, com Darwin ou Cuvier?"FOUCAULT, Michel. La situation de Cuvier dans l'histoire de la biologie. Revue d'histoire des sciences, v. 23, n. 1, p. 87-88, 1970. [Publicado também no segundo volume de Ditos e escritos].

Traduções sem indicação de tradutor são de minha responsabilidade.
} 
(Cartào-postal)

(Rio de Janeiro - Brasil

Gávea com praia vista do Dois Irmàos)

Joào,

"Por detrás está Granada.

E depois de ver as moças..."

Assim começou você em redondilhas o seu cartào de boas-festas.

Depois de ver as moças disse comigo, como aquele sujeito do conto de A. France': Je voudrais bien que les puces de mon lit fussent faites comme sa!

Obrigado pelo cartào, mas ele é meia ingratidão (respondo às redondilhas com esses dois octossilabos): quero carta, como as de Barcelona!

\section{Saudades e felicidades!}

Manuel.

[jan. 1957 ${ }^{10}$

Em "Eu gostaria que as pulgas da minha cama fossem feitas assim!", ou as pulgas são aí, "nonsensicamente" feitas; ou podemos parafrasear elas metonimicamente - em relação às redondilhas - como dispostas. Estas criaturas, por sua vez, provêm de Les matinées de la Villa Saïd, de "Le professeur Brown cherche le secret du génie", um conjunto de narrativas encadeado pela venda de um quadro de um retrato de Rabelais a Anatole France e de uma conversa com o professor e filólogo do título, que pesquisa nuances do gênio na literatura. Nesta estória, há a seguinte alusão: "Plut au Ciel, s'écrie-t-il, que toutes les puces de mon lit jussent pareilles à cette jeune mahométane! / Deus queira, ele afirma, que todas as pulgas da minha cama fossem parecidas a este jovem mahométane!"11 uma afirmação de Sancho ao Quixote, contida

${ }^{10}$ MELO NETO, João Cabral de. Correspondência de Cabral com Bandeira e Drummond. Organização de Flora Süssekind. Rio de Janeiro: Nova Fronteira / Fundação Casa Rui Barbosa, 2001, p. 150.

${ }^{11}$ FRANCE, Anatole. Les matinées de la Villa Saïd. Recueillis par Paul Gsell. Paris: Bernard Gras- 
no Segundo tomo del ingenioso hidalgo Don Quijote de la Mancha, citada por Dr. Brown, que conversa com um autoficcionalizado Anatole France. ${ }^{12}$ Ambos Brown e Anatole comentam no conto todo sobre as histoires de Avellaneda, Alonso Fernández de Avellaneda, o pseudônimo-publicador do Segundo tomo, do qual provém inúmeras interpretações e fabulações críticas sobre a origem do autor, da obra, suas relações com Cervantes, e, como o caso fomentador de discussões sobre autoria de Homero, essas interpretações se dividem entre "unitarismos" e "analiticismos", isto é, se Avellaneda era um ou se era mais. ${ }^{13}$

Bandeira é mais, sem dúvida, e talvez até tivesse contato com esta teia de relações em seu período de professor de literatura hispano-americana na UFRJ, chamada na época de "Universidade do Brasil", apesar do seu livro homônimo desta cadeira de Letras não destrinchar os limites do Quixote. ${ }^{14}$

Como dito anteriormente, Anatole também é mais. Ele mesmo é um personagem deste arrastado conto. E o ser mais - reafirmo que ser mais é ser uma construção - é a marca-mor de Cervantes, que é, inclusive, um personagem em sua própria obra:

set, 1921, p. 126. Anatole, ainda que considerado passadista por Mário de Andrade, tem um alto potencial de complexificação, como um pedaço da narrativa estar em rodapé, onde é apresentada uma personagem que muda o porquê do início da história ser a venda de um quadro.

12 Na verdade, a colocação de Brown também pode ser uma paráfrase, uma vez que não há nada próximo disso nos encontros de Sancho com mouriscos na edição de 1614. Cf. AVELLANEDA, Alonso Fernández de. Segundo tomo del ingenioso hidalgo Don Quijote de la Mancha: que contiene su tercera salida, y es la quinta parte de sus aventuras. Tarragona: Felipe Roberto, 1614; nem em cinco versões das Nouvelles Aventures de l'Admirable Don Quichotte de la Manche: composées par le licencié Alonso Fernández de Avellaneda, do séc. XVIII, ou em uma de 1828, traduções atribuídas a Alain-René Lesage ou somente à Compagnie des Libraires digitalizadas pelo Google Books e pela Biblioteca Virtual Miguel de Cervantes.

Na estória, Avellaneda é visto como tão importante quanto Cervantes, até elevado, dado o abandono do último à "espontaneidade" e a "piedade" do primeiro - sem observar que o próprio "plagiador" ironiza pesadamente a Inquisição em sua obra. "[...] la caricature servirait de repoussoir au radieux modèle. / [...] a caricatura serviria como um repoussoir para o modelo radiante." O repoussoir em si, o fundo escuro ou com formas escuras que desvelam maior profundidade na pintura, e, neste caso, uma alegoria, é quase simbiótica ao Quixote: Sancho é lido constantemente como foil, como este contraste, como o motor necessário à própria questão do fim que ironiza o romance de cavalaria, como alegoria ele mesmo. Cf. CORWIN, Norman. Holes in a Stained Glass Window. Secaucus: Lyle Stuart / Toronto: George J. McLeod, 1978, p. 45-47.

${ }^{13}$ Uma especulação corrente é que Avellaneda fora o espetador Lope de Vega. Cf. Cervantes contra Lope. Direção: Manuel Huerga. Guión: María Jaén. RTVE / Onza Entertainment / Minoría Absoluta, 5 dec. 2016.

Não seria exagero, ainda, apontar Avellaneda como uma variedade de um Pierre Ménard. BORGES, Jorge Luis. Pierre Menard, autor del Quijote. [Ficciones]. Obras completas 19231949. v. 1. Buenos Aires: Emecé, 2004, p. 444-450.

${ }^{14}$ BANDEIRA, Manuel. Literatura hispano-americana. Rio de Janeiro: Irmãos Pongetti Editores, 1949. 
- Este - prosseguiu o barbeiro - é o Cancionero de López Maldonado.

- O autor desse livro também é grande amigo meu — respondeu o padre. - Os versos dele, em sua própria boca, causam admiração a quem os ouve; e tamanha é a suavidade da voz com que os canta, que encanta. É um pouco longo nas églogas, mas nunca o bom foi muito. Guarde-se com os escolhidos. Mas que livro é esse que está perto dele?

- A Galateia de Miguel de Cervantes - disse o barbeiro.

- Há muitos anos que esse Cervantes é grande amigo meu, e sei que é mais versado em infortúnios que em versos. Seu livro tem alguma coisa de boa invenção: propõe algo mas não conclui nada. É preciso esperar a segunda parte que promete: talvez com a emenda alcance de todo a misericórdia que agora lhe é negada. ${ }^{15}$

Como lidar, então, com estes seres ficcionalizados?

\section{PEQuenOS NADAS}

É possível ler Bandeira sem ater totalização alguma, bem como é possível ler o próprio Quixote assim. ${ }^{16}$ Bandeira move o "conteúdo emocional", articulado com a natureza artística, que não precisa passar por um todo biografado que une os diversos sujeitos-Bandeira. Está "à escuta" de si, dos sentimentos, do sopro artístico que passa por ele. Há, aí, lucidez valeriana - "É melhor ter composto uma obra medíocre com toda a lucidez do que compor uma obra prima em transe..." 17 Disso, decorre imediatamente um pensar a aurea mediocritas e uma confirmação do humilde, ou mergulharmos em transe naquilo que se esvai - sobre o que e a quem repercutiu a produção de Manuel Bandeira? E qual a relação disso para onde ele nos leva? (Pasárgada?)

${ }^{15}$ CERVANTES, Miguel de. Dom Quixote. Tradução de Ernani Ssó. São Paulo: Schwarz, 2012. [Penguin Companhia: Clássicos / Companhia das Letras. Recurso digital]. Citações diretas sem página são acompanhadas de um aviso nas referências de que se trata de um recurso eletrônico de paginação que varia de acordo com a resolução do suporte utilizado para ler.

${ }^{16}$ Borges, sem nos atermos à questão da universalidade da história ou da literatura, distende o problema até o leitor, passando pelo palco em cena de Hamlet: "Por que nos inquieta que dom Quixote seja leitor do Quixote e Hamlet espectador de Hamlet? Creio ter dado com a causa: tais inversões sugerem que, se os personagens de uma ficção podem ser leitores ou espectadores, nós, seus leitores ou espectadores, podemos ser fictícios." BORGES, Jorge Luis. Magias parciais do Quixote. Tradução de Davi Arrigucci Jr. In: Ibidem.

${ }^{17}$ BANDEIRA, Manuel. [Itinerário de Pasárgada]. Poesia completa e prosa: em um volume, op. cit., p. 39. 


\section{PRODUÇÃO PERIODISTA (OU A POLÍTICA PERIODISTA)}

Adelmo Genro Filho, no clássico O segredo da pirâmide, recupera, para abordar respiros militantes no jornalismo, um Habermas de Mudança estrutural da esfera pública, onde o jornal não é tido como reduzido ao nominalismo nem a uma e necessariamente uma ideologia adjacente que uniria a angulação midiática. ${ }^{18}$ Totalização, a ferramenta mais apaixonada dos censores. Retomo este militante do Partido Revolucionário Comunista (PCR, atuante de 1984 a 1989), pela abordagem que ele dá ao marxismo.

Não há uma referência ao marxismo ou ao comunismo sequer, nas Crônicas da província do Brasil, em Flauta de papel, ou nos poemas bandeirianos onde estes significantes não são lidos na chave do ultraesquerdismo:

\section{A JORGE MEDAUAR ${ }^{19}$}

\section{Há TRINTA aNOS (tanto corre O tempo) escrevi a poesia Onde disse que fazia Meus versos como quem morre.}

Ainda não eras nascido. Agora, orgulhosamente Moço, ao poeta velho e doente Parodiaste destemido:

Das batalhas em que estive E o suor que em men verso escorre! Tu o fazes como quem morre: Eu o faço como quem vive!

Façam-no como quem morre Ou quem vive. que ele viva! Vive o que é belo e deriva Da alma e para outra alma corre.

18 GENRO FILHO, Adelmo. O segredo da pirâmide: para uma teoria marxista do jornalismo. Porto Alegre: Tchê, 1987, p. 108.

19 BANDEIRA, Manuel. Mafuá do malungo. Poesia completa e prosa: em um volume, op. cit., p. 405.

Curiosamente, Sebastião Nery tem uma crônica sobre Medauar sobre duas personas, o escritor e um político da ARENA. NERY, Sebastião. [Jorge Medauar, baiano, poeta, ...] 976. Folclore político: 1950 histórias. Geração Editorial, 2002, p. 318. O banco de dados do CPDOC | FGV aponta que havia, de fato, outro Medauar, um político. E aí se abre mais uma possibilidade de entrelaçamento varrido ou recorrente coincidência de teias da rede em torno de Bandeira. 


\title{
Verso que dela se prive, Ai dele! quem lhe socorre? \\ Nem Marx nem Deus! Ele morre. \\ Só o verso com alma vive. \\ Deste ou daquele pensar, Esta me parece a reta, A justa linha do poeta, Poeta Jorge Medauar!
}

\begin{abstract}
O socialismo também não se salva. Lemos em uma das Crônicas da província do Brasil, "Arquitetura brasileira":

A GUERRA DE 1914 provocou em todo o mundo uma como revivescência do sentimento nacional, que andava adormecido por várias décadas de propaganda socialista ativa. As elites sonhavam com uma organização política e social mais justa numa humanidade sem fronteiras. Mal, porém, se declarou o conflito, o espírito feroz de pátria apoderou-se de todos, inclusive de socialistas. ${ }^{20}$
\end{abstract}

Ainda que o Partido Socialista do Brasil (PSB) tenha sido aturável a ponto de uma candidatura, e um "socialista" em particular seja absolvível:

Há [um] parti pris de propaganda socialista: todos os proletários são bons, ou pelo menos desculpáveis, e o resto da humanidade que passa no romance, umas pestes. Ninguém melhor que Jorge Amado sabe que a vida não é tão simples assim. Num romancista essa vista grossa desumaniza inteiramente as suas personagens. Elas cessam logo de interessar, e adeus a própria propaganda. Mais inteligente será mostrar que misérias e maldades de todos, ricos ou pobres, decorrem da organização social defeituosa no regime sob que vivemos. ${ }^{21}$

Adelmo tampouco era stalinista - foi do PCR e não do Partido Comunista do Brasil (PCdoB) justo por não compactuar com os andamentos no Araguaia. E talvez ele possa ser bibliografia essencial para encarar o tabaco solto de um Bandeira que, simultaneamente, ao reclamar dos modernismos, ou melhor, das vanguardas, especialmente se presente nos malungos, e ao esperar uma visão sórdida do regime a que eles estão submetidos, recusa-se à política:

20 Idem, Arquitetura brasileira. Poesia e prosa. v. II. Rio da Janeiro: José Aguilar, 1958. Todas as citações estão em sic erat scriptum, dispensando o uso de sic em cada "desvio".

${ }^{21}$ Idem, Impressões literárias. Poesia e prosa, op. cit., p. 1195. [Excerto VII da seção do Diário de notícias, também "Impressões literárias"]. 


\title{
VARIAÇÕES \\ SOBRE O NOME DE MÁRIO DE ANDRADE ${ }^{22}$
}

\author{
Positivamente esta quarta-feira está cotidiana demais \\ O leite da manhã tinha mais água \\ O sol está banal como uma taça de campeonato \\ Como os bronzes comerciais que representam o Trabalho \\ Eu não sei latim \\ Não sei cálculo diferencial e integral. \\ Não sei tocar piano (por causa de uma sonatina de Steibelt) \\ Não compreendo absolutamente Fichte Schelling e Hegel
}

\author{
Victor Hugo é pau \\ Byron é pau \\ Mário um cigarro \\ CAPORAL LAVADO!
}

Bandeira se exime de atrelar sua atividade à "poesia de combate", mas não deixa, nunca, de contar histórias. ${ }^{23}$

\section{Periodismo}

Alexandre Pilati classifica o periodismo dos anos 20 como alavancador do(s) modernismo(s) - não no sentido estrito a vanguardas, mas amplo e paralelo ao desenvolvimento do jornalismo no Brasil. O sentido de periodismo, aí, é o de divulgação, operado por marketização. Marketing, aí, não

22 Idem, Mafuá do Malungo. Poesia completa e prosa, op. cit., p. 388 [Trecho].

${ }^{23}$ O biografista Marco Antonio de Carvalho satiriza: "até um remotamente politizado Manuel Bandeira" assina o manifesto do PSB, o próprio que Antonio Candido ajuda a fundar, junto de Rubem Braga, Joel Silveira e Sérgio Buarque de Holanda. CARVALHO, Marco Antonio de. Rubem Braga: um cigano fazendeiro do ar. São Paulo: Globo Livros, 2007, p. 313.

Nesta mesma linha, Dário Borim Jr. aponta como Bandeira deixa pouco espaço ao engajamento, mas não deixa de ser transparente ao dispor a "[...] despretensão com que registra seu 'Testemunho': 'Sou poeta menor, perdoai!/ Não faço versos de guerra./ Não faço porque não sei'”. BORIM JR., Dário. O laço e a corda bamba: Um estudo sobre a poética menor e o desacerto ideológico de Manuel Bandeira. Chasqui, v. 19, n. 1, p. 32, maio 1990.

O tom leve empregado pelo poeta sobre a sua candidatura a João Cabral também demonstra isso: "Saiba, meu caro, que sou candidato a deputado!!! V. me vê, já não digo deputado, mas candidato a deputado? Do meu partido (o socialista) me telefonaram pedindo-me autorização para incluir o meu nome na chapa. Respondi que não tinha jeito para a política, que não os podia auxiliar em nada. - Você já auxilia muito dando o seu nome. Que é que eu havia de opor? Pois então que levassem o nome! Claro (felizmente) que não há a menor mínima possibilidade de eu ser eleito." BANDEIRA, Manuel. 97. A João Cabral de Melo Neto. Poesia e prosa, op. cit., p. 1450. 
possuiu um sentido pejorativo, mas que "No fundo, o jornal se torna, mais que um veículo de difusão, o prisma por meio do qual cotidianamente eram articulados os fatos do novo Brasil à estética do novo Brasil."24

Este dado é do livro Manuel Bandeira en Pasárgada, um conjunto de ensaios que abordam, também, o periodismo que perpassa Bandeira tanto em sua produção crítica quanto poética; que inclui tanto a "arquitetura da palavra" quanto a crítica sobre a arquitetura. As revistas - Terra Roxa, Klaxon, Estética, A Revista... - são o outro lado, aquele em que salta este primeiro sentido de arquitetura.

Em Bandeira, vemos um ele sobre ele mesmo que nunca se encerra, um ser libertino, e que prefere não escutar passivamente à censura. Com estas considerações, resta-nos não censurar e não nos censurarmos da arte da crônica, uma vez que esta elaboração não se limita a versos. ${ }^{25}$

A respeito de Bandeira, a produção crítica periodista - não periodística, que é o que compõe o lide da matéria jornalística - é condensada em grande esforço pelo filólogo membro da Academia Brasileira de Filologia, Maximiano de Carvalho e Silva, em Homenagem a Manuel Bandeira, publicado em 1936. ${ }^{26}$ Periodismo, agora, é uma máxima acadêmica, não só no sentido universitário, mas investigativo. A presença de nomes como Candido, Alphonsus de Guimarães, Drummond, Gilberto Freyre, Ivan Junqueira, Otto

${ }^{24}$ PILATI, Alexandre. Fermento literário e humor dissolvente: a experiência brasileira nos poemas bandeirianos de "Bife à moda da casa". In: HERNÁNDEZ, Ascensión Rivas (Ed.). Manuel Bandeira en Pasárgada, op. cit., p. 152.

${ }^{25}$ No limite, o caminho aqui percorrido passa por uma cisão análoga a de Benjamin em relação às correspondências de Schlegel e Novalis, das conferências e aulas do primeiro e de como de ambos é extraído um sujeito não totalizável, mas que ainda mantém um caminho não infindável e vazio [de pensamento] (ein endloser und leerer Verlauf) BENJAMIN, Walter. $O$ conceito de crítica de arte no romantismo alemão. Tradução de Marcio Seligmann-Silva. São Paulo: lluminuras, 1999; ou a de como Deleuze chega, também, a um sujeito ilimitado pelo corpo sem órgãos do Artaud de Pour en finir avec le jugement de dieu. DELEUZE, Gilles. Lógica do sentido. Tradução de Luiz Roberto Salinas Fortes. São Paulo: Perspectiva, 1999; ou ainda às linhas-caminhos a partir de $A$ fenda aberta de Fitzgerald. Idem, A dobra: Leibniz e o barroco. Tradução de Luiz B. L. Orlandi. Campinas: Papirus, 1991; DELEUZE, Gilles; GUATTARI, Félix. Mil platôs: capitalismo e esquizofrenia. v. 1. Tradução de Aurélio Guerra Neto e Célia Pinto Costa. Rio de Janeiro: Editora 34, 1995; v. 4. Tradução de Suely Rolnik. Rio de Janeiro: Editora 34, 1997.

Capela, discorrendo sobre a infinitude de caminhos das "Viagens de Ahasverus à terra alheia em busca de um passado que não existe porque é futuro e de um futuro que já passou porque sonhado", de Rawet, também trata do enigmático infindável. CAPELA, Carlos Eduardo Schmidt. Derivas integrais. Literatura: teoría, historia, crítica, v. 16, n. 1, p. 81-105, 2014.

${ }^{26}$ SILVA, Maximiano de Carvalho e (Org.). Homenagem a Manuel Bandeira 1986-1988. Rio de Janeiro: Sociedade Sousa da Silveira / Monteiro Aranha / Presença Edições, 1989 [1936]. 
Lara Rezende, Massaud Moisés, um médico e até de um brasileiro brasilianista sustentam a afirmação de Ana Mariza Ribeiro Filipouski e Atelaine Norman, autoras de um texto didático, "Literatura brasileira e portuguesa", do Novo manual de português, de Celso Luft. Para elas, foi o Homenagem que alavancou Bandeira à academia e à Academia. ${ }^{27}$

O médico, Aloysio de Paula, lê o poeta através de oscilações vitais esvaídas da condição tísica, ressaltando que, a despeito disso, "Nada era banal em Bandeira. Uma tarde fui visitá-lo e, para começo de conversa, pediu à companheira: traga os óculos de ouvir. Havia sempre um imprevisto em tudo o que dizia, a que não faltava nunca uma graça espontânea no modo como via e comentava tudo o que ia acontecendo em torno da nós." 28

Em uma outra crônica ainda, "O sonho de França Júnior", Bandeira ironiza e ao mesmo tempo concorda com um Pedro Dantas que exalta a pintura de França Júnior e ataca a "pilhéria antropofágica". Neste caso, retomando a questão do ser crítico, há até uma cisão deste como atrelado ao criativo: “Em suma, a pilhéria antropófaga era boa, não como pilhéria, mas como observação crítica. França Júnior e Antônio de Alcântara Machado são dois anotadores insignes dos nossos costumes." 29 Aos malungos, portanto, a "graça espontânea"; não no sentido divino, mas de leveza e comicidade, mesmo ao tomar uma posição. À história, Bandeira tampouco relega uma expectativa de ruptura, como os críticos - não só nos meios de crítica de arte. ${ }^{30}$

${ }^{27}$ FILIPOUSKI, Ana Mariza Ribeiro; NORMAN, Atelaine. Literatura brasileira e portuguesa. LUFT, Celso Pedro (Org.). Novo manual de português: gramática, ortografia oficial, redação, literatura, textos e testes. São Paulo: Globo, 1991.

${ }^{28}$ PAULA, Aloysio de. A doença de Manuel bandeira. In: SILVA, Maximiano de Carvalho e (Org.). Homenagem a Manuel Bandeira 1986-1988, op. cit., p. 52.

A não banalidade através de operações criativas, isto é, a produção consciente é o que leva Sílvio Elia a denominar o poeta de "prosador maior". Não só pela "escorreita da linguagem, clareza e elegância de estilo, justeza de vocabulário", que perpassa o recorte analisado pelo autor: a atuação de Bandeira no jornal $A$ Noite; o destaque da alternância de "Abaixo os puristas" e "Abaixo a Revista de Língua Portuguesa!" uma revista por onde passaram, justamente, alguns poemas de Ritmo dissoluto, inclusive o que contém este verso, "Poética"; análises de Carnaval, Libertinagem e A cinza das horas; e principalmente comentários filológicos a partir de Noções de história das literaturas, de onde se afirma: "Trata-se de livro didático, mas é obra de nível superior. Aí o prosador, em pleno domínio de suas responsabilidades docentes, não faz concessões aos verdores agramaticais da primeira juventude." ELIA, Silvio. O prosador Manuel Bandeira. In: SILVA, Maximiano de Carvalho e (Org.). Homenagem a Manuel Bandeira 1986-1988, op. cit., p. 527-534.

${ }^{29}$ BANDEIRA, Manuel. Crônicas da província do Brasil. Poesia e prosa, op. cit., p. 171.

${ }^{30} \mathrm{Em}$ um texto para a Argumento, o escritor uruguaio Ángel Rama critica Bandeira como um dos totalizadores da história, no caso de Literatura hispano-americana, como um braço uni- 
Além disso, sobre a produção do poeta não ser dádiva, ou melhor, graça divina, o brasilianista citado anteriormente, Wilson Martins, que ironiza o "catolicismo crítico" do poeta, posiciona-se contra o que, para ele, eram as consequências das leituras semiológicas que cresciam na época e ainda pontua a dificuldade de ler esse poeta "fácil". Também acrescenta uma pungência marcante sobre o ser baixo:

versalizante do que, na verdade, deveria ser analisado de lados mais particulares e - conscientemente - datados da expressão literária. RAMA, Ángel. Um processo autonômico: das literaturas nacionais a literatura latino-americana. Tradução de Nestor Deola. Argumento: Revista Mensal de Cultura, v. 1, n. 3, p. 36-49, jan. 1974.

Argumentando que este livro do poeta tinha um princípio didático em si, Pedro Theobald posiciona Bandeira ao lado do universalismo de Otto Maria Carpeaux. THEOBALD, Pedro. A História da literatura ocidental de OM Carpeaux e a crítica de Wilson Martins. Letrônica, v. 11, n. 3, p. 140-145, 2018.

Este tangenciamento, entretanto, parece artifício para escapar das problemáticas do universalizante. Uma censura que toma sempre o crítico como a verdade, onde se prioriza o que constitui glosa frente a uma sustentável unidade. O próprio pernambucano não toma esta posição em uma crônica que podemos nos identificar facilmente: "E que dizer de uma obra de história, de sociologia, de política, de moral? Pobre do crítico nosso, um Sílvio Romero, um Veríssimo, um Tristão de Ataíde, um Álvaro Lins, professôres mal pagos e obrigados a outras tarefas, que recebem de repente livros densos como Os Sertões, as Populações Meridionais, Casa-Grande \& Senzala, as Raízes do Brasil... e têm de os ler, assimilar e julgar nos lazeres quase inexistentes do seu ganha-pão inadiável! No entanto há que o fazer, porque a vida não espera, principalmente no Brasil ..." BANDEIRA, Manuel. A crítica. [Flauta de papel]. Poesia e prosa, op. cit., p. 268.

Se tomada a multiplicidade de ainda mais meios de fortuna, confirma-se ainda que "A poesia fala uma língua. A História, outra." Aforismo de que parte Leminski - considerando o caráter polímata de Bandeira, Drummond, Cabral, Murilo e Mario como essencial para a "poesia desprevenida" - para exaltar a poesia como inacabamento e o conto como "flagrante delito" democrático ainda que meio brega, "O conto é o soneto de hoje." LEMINSKI, Paulo. Sobre poesia e conto: um depoimento. Escrita: revista mensal de literatura, n. 28, p. 54-58, 1979.

Como a Travessia, as revistas candidatas à crítica-mor que tratam da obra poética bandeiriana em si são a Almanaque: Cadernos de Literatura e Ensaio (1976-1982) e a Anhembi (19501962) (no caso da segunda, o poeta seria até um dos modelos para o exaltável, especialmente antes da década de 60. FRANÇA, George Luiz. Anhembitinerários ou algum modernismo passado a limpo. Boletim de Pesquisa NELIC, v. 7, n. 10, p. 54, 2007; especialmente ao longo da crítica de Sérgio Milliet.) Além, claro, da própria vasta recorrência de Arrigucci Jr., seja na própria Almanaque, seja no Folhetim (1977-1989), seja no Letras (1989-1992), ambos suplementos da Folha, seja até em um texto específico, "No mínimo, poeta", para a Cult: revista brasileira de literatura (1997-). O poeta também marca presença na Novos Estudos CEBRAP (1981-), na Tempo Brasileiro (1962-), na Azougue (1996-2008), na Revista de poesia e crítica (1976-1996), na Revista USP (1981-) e na Revista do Brasil (1984-1990). Nestas, Bandeira surge mais como uma voz inseparável da poesia no Brasil, onde ressaltam reincidências de experimentalismo, erotismo, desenvolvimento - artístico, literário, poético - e, relevantemente para o caso do presente texto, consciência. Os casos especiais são o da Sibila (2001-), onde a reincidência preponderante é de um Bandeira crítico, e da 34 Letras (1988-1990), de um Bandeira tradutor. Dados extraídos da base de dados do NELIC, não exaustivos e aqui somente constam as menções mais frequentes, não os numerosos esparsos. Vale destacar também que nenhum crítico além de Arrigucci Jr. contém mais de um texto no qual o poeta seja o tema em questão. 
Foi, antes de mais nada, um autor que se entregou à facilidade nativa, que aceitou de bom grado a sua condição, não de 'altíssimo poeta', como diriam os italianos, mas de 'uomo qualunque' da poesia brasileira. Muitos dos seus poemas do anedóticos e mais espirituosos do que espirituais; outros, meramente circunstanciais e históricos, de onde tiram, aliás, todo o interesse. Entre eles, claro está, as três

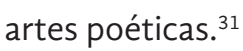

Finalizando sinteticamente, retomo as palavras de Antelo sobre os choques entre udenistas e "comunistas de Literatura" que culminavam em autoritarismos de 1933 a 1948:

A ambição de uma explicação global e abrangente teve uma consequência inevitável: o dogmatismo que se exprime na explanação cabal do passado, na idéia de um presente sob custódia e na previsão infalível do futuro. Tal atitude nega, implicitamente, a abertura da ambiguidade, que é essencial ao literário, invalidando, de cambulhada, a linguagem indireta da reflexão pelo mesmo motivo: sua equivocidade. Assim, ao negar a ficção como uma forma de conhecimento, o pensamento dogmático instaura-se, ele próprio, como mera ficção de conhecimento. ${ }^{32}$

Por isso, o título: ficção ou poesia, sem o caráter exclusivo de ou - como em Lascaux ou o nascimento da arte - a partir do qual prosamos sobre o devir-ficção de Bandeira, em suas inúmeras formas.

${ }^{31}$ MARTINS, Wilson. Sobre Manuel Bandeira. In: SILVA, Maximiano de Carvalho e (Org.). Homenagem a Manuel Bandeira 1986-1988, op. cit., p. 573.

32 ANTELO, Raúl. Literatura em revista. Tese (Doutorado) - Departamento de Letras Clássicas e Vernáculas, Faculdade de Filosofia Letras e Ciências Humanas, Universidade de São Paulo, 1981, p. 346-347. 